\title{
On the Influence of Vegetation Cover Changes and Vegetation-Runoff Systems on the Simulated Summer Potential Evapotranspiration of Tropical Africa Using RegCM4
}

\author{
Samy A. Anwar ${ }^{1}$ (D) . Ossénatou Mamadou ${ }^{2,3} \mathbb{E} \cdot$ Ismaila Diallo $^{4}$ (D) Mouhamadou Bamba Sylla ${ }^{5}$ (D)
}

Received: 19 March 2021 / Revised: 14 August 2021 / Accepted: 15 August 2021 / Published online: 15 September 2021

(c) The Author(s) 2021

\begin{abstract}
The community land model version 4.5 provides two ways for treating the vegetation cover changes (a static versus an interactive) and two runoff schemes for tracking the soil moisture changes. In this study, we examined the sensitivity of the simulated boreal summer potential evapotranspiration (PET) to the aforementioned options using a regional climate model. Three different experiments with each one covering 16 years have been performed. The two runoff schemes were designated as SIMTOP (TOP) and variable infiltration capacity (VIC). Both runoff schemes were coupled to the carbon-nitrogen (CN) module, thus the vegetation status can be influenced by soil moisture changes. Results show that vegetation cover changes alone affect considerably the simulated 2-m mean air temperature (T2M). However, they do not affect the global incident solar radiation (RSDS) and PET. Conversely to the vegetation cover changes alone, the vegetation-runoff systems affect both the T2M and RSDS. Therefore, they considerably affect the simulated PET. Also, the CN-VIC overestimates the PET more than the CN-TOP compared to the Climatic Research Unit observational dataset. In comparison with the static vegetation case and CN-VIC, the CN-TOP shows the least bias of the simulated PET. Overall, our results show that the vegetationrunoff system is relevant in constraining the PET, though the CN-TOP can be recommended for future studies concerning the PET of tropical Africa.
\end{abstract}

Keywords Tropical Africa $\cdot$ Regional climate model $\cdot$ Potential evapotranspiration $\cdot$ Climatic Research Unit $\cdot$ Runoff scheme $\cdot$ Carbon-nitrogen

Samy A. Anwar

ratebsamy@yahoo.com

Ossénatou Mamadou

ossenatou.mamadou@imsp-uac.org

Ismaila Diallo

idiallo.work@gmail.com

Mouhamadou Bamba Sylla

syllabamba@yahoo.fr

1 Egyptian Meteorological Authority, Qobry EL-Kobba, P.O. Box 11784, Cairo, Egypt

2 Institute of Mathematics and Physical Sciences (IMSP), University of Abomey-Calavi, Dangbo, Benin

3 Laboratoire de Physique du Rayonnement, University of Abomey-Calavi, Abomey-Calavi, Benin

4 Department of Meteorology and Atmospheric Science, Center for Earth System Modeling, Analysis, and Data (ESMAD), The Pennsylvania State University, University Park, PA 16802, USA

5 African Institute for Mathematical Sciences (AIMS), AIMS Rwanda Center, Kigali, Rwanda

\section{Introduction}

Among different processes within the terrestrial hydrological cycle, evapotranspiration (ET) plays an important role in determining the global water balance and linking the global water, energy and carbon cycles (Pielke et al. 2002; Bonan 2008; Yang 2015). Indeed, it controls the retroactions between land and atmosphere through energy fluxes (Mamadou et al. 2014, 2016) and thus sustains precipitation (Taylor et al. 2012; Nicholson et al. 2013; Koster et al. 2004). The 'potential evapotranspiration' (PET) however, can be seen as the amount of the water vapor that would evaporate if a sufficient water source is available. Estimation of the PET is valuable for many operational applications especially in agriculture and hydrology. Indeed, PET is required for estimating the crop water requirements, supporting irrigation scheduling, drought management, and climate change studies. Furthermore, it is an important input to a variety of hydrological model applications 
(Andréassian et al. 2004; Vicente-Serrano et al. 2014). Numerous formulations of the PET exist in literature. However, the most used and called 'the Penman-Monteith method (PM)', has been proposed by Allen et al. (1994). Indeed, they defined the PET for a hypothetical reference crop of $0.12 \mathrm{~m}$ height, bulk surface resistance of $70 \mathrm{~s} \mathrm{~m}^{-1}$, and albedo of 0.23 assuming active green grass. In addition, Allen et al. (1998) calculated the PET using a process-based approach. This approach needs many meteorological inputs including the $2-\mathrm{m}$ air temperature (T2M), 2-m relative humidity, and near surface wind speed (see Eq. 1). Kjelgaard and Stokes (2001) calculated the PET (or $\lambda E$ as a source of latent heat flux) as follows:

$\lambda E=\frac{\Delta s\left(R_{n}-G\right)+\rho_{\mathrm{a}} c_{\mathrm{p}} \frac{\mathrm{VPD}}{r_{\mathrm{a}}}}{\Delta s+\gamma\left(1+\frac{r_{\mathrm{s}}}{r_{\mathrm{a}}}\right)}$,

where:

$\lambda E, R_{n}$, and $G$ are expressed in $\mathrm{W} \mathrm{m}{ }^{-2}$, VPD is the vapor pressure deficit $(\mathrm{kPa}), \Delta s$ is the slope of saturation vapor pressure curve $\left(\mathrm{kPa}{ }^{\circ} \mathrm{C}^{-1}\right)$ at 2-m air temperature, $\rho_{\mathrm{a}}$ is the density of air $\left(\mathrm{kg} \mathrm{m}^{-3}\right), c_{\mathrm{p}}$ is the specific heat of the air $\left(\mathrm{J} \mathrm{Kg}^{-1}{ }^{\circ} \mathrm{C}^{-1}\right), \gamma$ is the psychrometric constant $\left(\mathrm{kPa}^{\circ} \mathrm{C}^{-1}\right), r_{\mathrm{a}}$ is aerodynamic resistant $\left(\mathrm{s} \mathrm{m}^{-1}\right), r_{\mathrm{s}}$ is the surface resistance to vapor transport $\left(\mathrm{s} \mathrm{m}^{-1}\right)$.

Besides, the PM method was recommended by the Food and Agriculture Organization of the United Nations (FAO) to accurately estimate the PET from climate data (Allen et al. 1998). Due to the numerous meteorological variables which are not often all available, alternative approaches that consider limited meteorological inputs are needed. Since the 1940s, several empirical methods have been developed. These methods can be grouped into five categories: (1) water budget (Guitjens 1982), (2) mass-transfer (Harbeck 1962), (3) combination (Penman 1948), (4) radiation (Priestley and Taylor 1972), and (5) temperature-based (Thornthwaite 1948). Among these, the temperature-based ones offer an interesting option to study the future projected PET. Hargreaves method (hereafter HG; Hargreaves and Allen 2003) is the best alternative method for quantifying the PET because of its ability to capture information relative to the land surface property, such as soil moisture and albedo through the diurnal temperature range (Almorox et al. 2015; $\mathrm{Li}$ et al. 2018). Note that, this approach has been widely applied and evaluated across different climate regions with good performance (Droogers and Allen 2002). According to the HG method, PET is computed as:

$\operatorname{PET}_{\mathrm{HG}}=0.0023 \times R_{\mathrm{a}} \times\left(T_{\max }-T_{\text {min }}\right)^{0.5} \times\left(T_{\text {mean }}+17.8\right)$,

where PET $_{\mathrm{HG}}$ is the daily PET (unit: $\mathrm{mm} \mathrm{day}^{-1}$ ); $\mathrm{R}_{\mathrm{a}}$ is the extra-terrestrial radiation for a given day and latitude; $T_{\max }$,
$T_{\text {min }}$, and $T_{\text {mean }}$ are the daily values of maximum, minimum, and mean air temperature at $2 \mathrm{~m}$ above the surface $\left({ }^{\circ} \mathrm{C}\right)$ respectively. When the global incident solar radiation (RSDS) is readily available, Eq. (2) can be rewritten as follow:

$\mathrm{PET}_{\mathrm{HG}}=0.0135 \times \mathrm{RSDS} \times\left(T_{\text {mean }}+17.8\right)$.

$R_{\mathrm{a}} / \mathrm{RSDS}$ is expressed in units of mm day ${ }^{-1}$ to show how much energy is used to evaporate water (Allen et al. 1998). Performance of the HG method with respect to the other approaches has been highlighted in various studies. For instance, Er-Raki et al. (2010) found that the HG method is the best to calculate PET compared to the PM formula. Sperna et al. (2012) recommended calibrating the HG equation to calculate the PET compared to the Climatic Research Unit (CRU) gridded product. Likewise, Sheikh and Mohammadi (2013) showed the superior performance of the HG method over the other empirical methods, with the HG showing the least compared to the PM observations. By comparing the PET obtained by different methods (e.g. HG) using either station data or CRU gridded data, Potop and Boroneant 2014) showed that the HG method gives results closer to the CRU-PET data at the Chisinau station. Finally, Murat et al. (2017) found that the modified HG equation can give a relatively precise estimate of the PET compared to the PM observations.

Recently, regional climate models (e.g. RegCM4) were used to study the influence of vegetation cover/fraction changes on the tropical African climate (Wang et al. 2015; Yu et al. 2015; Erfanian et al. 2016). For instance, Yu et al. (2015) studied the future climate changes of West Africa using the RegCM4 model. They observed that the future precipitation changes are reversed as a result of changes in the vegetation cover. In addition, the RegCM4 model was used to examine the role of runoff parameterization in constraining the surface climate of tropical Africa (Anwar et al. 2019). These authors showed that the Variable Infiltration Capacity (shortly VIC; Liang et al. 1994) runoff scheme is better than the SIMTOP (hereafter TOP; Niu et al. 2005) runoff scheme for simulating the tropical African climate. Adeniyi (2019) utilized the RegCM4 model to examine the potential influence of the total solar irradiance (TSI) on the precipitation, temperature, evapotranspiration, water availability for plant, and heat stress over West Africa. In general, the RegCM4 showed a good capability to capture the diurnal precipitation trend, intra-annual variations of precipitation, and temperature over West Africa. Furthermore, it was found that increase (decrease) of TSI results in increase (decrease) of the aforementioned variables. The influence of the two runoff schemes (TOP and VIC) on the terrestrial carbon cycle of tropical Africa with this model revealed that the runoff scheme has a considerable influence on the terrestrial 
carbon cycle of tropical Africa (Anwar and Diallo 2021a). Also, the VIC runoff scheme shows superior performance over the TOP runoff scheme for simulating the net ecosystem exchange (NEE).

Anwar and Diallo (2021b) showed that considering changes in the leaf area index (LAI), the RegCM4 model bias is amplified. However, the VIC runoff scheme still outperforms the TOP scheme relative to the static case. In a most recent study, Anwar and Diallo (2021c) found that the gross primary production (GPP) is more sensitive to the vegetation-runoff systems than when the vegetation cover changes alone. In addition, the GPP can be properly simulated when the VIC surface dataset is calibrated with respect to reanalysis products and/or in-situ observations. Finally, Anwar and Diallo (2021d) utilized the RegCM4 model to examine the potential influence of the new LAI formula on the surface energy balance and surface climate of tropical Africa. They found that utilizing the new LAI formula leads to a better performance (than using the old LAI formula) in simulating the surface energy balance and surface climate with respect to reanalysis products. While many studies have focused on the tropical African climate using different physical configurations, none of them focusing on PET and in particular on the influence of the vegetation cover changes alone and vegetation-runoff systems in simulating the boreal summer PET climatology. This paper aims to examine the sensitivity of the simulated boreal summer PET to the vegetation cover changes alone (as represented by LAI) and vegetation-runoff systems using the RegCM4 model. Section 2 describes the study area, experiment design, and validation data. Section 3 shows the results of the study. Section 4 provides the discussion, and while conclusions are presented in Sect. 5.

\section{Study Area, Data, and Methodology}

\subsection{Model Description}

The regional climate model version 4.5.0 (hereafter RegCM4; Giorgi et al. 2012) was used in the present study. RegCM4 is a limited area model and has been used for numerous studies including process studies (Sylla et al. 2015; Diallo et al. 2016; Kébé et al. 2020) and future climate projections (Diallo et al. 2016; Sawadogo et al. 2020; Ashfaq et al. 2020; among others). Performance of the RegCM4 model has been examined in tropical Africa as in Ogwang et al. (2016); Komkoua et al. (2017) and N'Datchoh et al. (2018). The selected physical configuration is documented in Anwar and Diallo (2021a; b, c, d). Recently, the Community Land Model version 4.5 (CLM45; Oleson et al. 2013) is coupled to the RegCM4. The CLM45 simulates various complex biogeophysical processes such as absorption, reflection, and transmittance of solar radiation, absorption, and emission of long wave radiation. Also, it includes complex biogeochemical processes such as photosynthesis and vegetation phenology.

In the CLM45 model, vegetation can be treated in three ways:

1. Prescribed vegetation (e.g. leaf area index [LAI]) derived from the Moderate Resolution Imaging Spectroradiometer (MODIS). This mode is known as Satellite Phenology (SP; Lawrence et al. 2011).

2. Prediction of vegetation cover changes (e.g. LAI) using a prognostic carbon-nitrogen model $(\mathrm{CN}$; Thornton and Rosenbloom 2005) to simulate/predict the seasonal variation of vegetation structure with a prescribed vegetation demography.

3. Prediction of both vegetation cover and fractional percentage using the $\mathrm{CN}$ model combined with a dynamic vegetation module (DV; Levis et al. 2004).

In addition, the CLM45 model has two runoff schemes:

1. SIMTOP (TOP; Niu et al. 2005). In the TOP runoff scheme, both surface and sub-surface runoff generation are predicted based on knowledge of the fractional saturated area, which in turn is determined by topographic characteristics and soil moisture state of a grid cell. Moreover, the total runoff distributed over the land grid is constituted by surface, sub-surface runoff, and liquid runoff from different sources (glacier, wetlands, and lakes).

2. Variable infiltration capacity (VIC; Liang et al. 1994). The VIC is a large-scale, semi-distributed hydrologic model. Basically, the VIC model requires the knowledge of four parameters $\left(B_{\text {inf }}, D_{\text {smax }}, D_{\mathrm{s}}\right.$ and $W_{\mathrm{s}}$ ) to calculate the surface, sub-surface, runoff and related surface variables (e.g. energy balance). These four parameters are provided in a global surface dataset. $B_{\text {inf }}$ is a parameter that controls the shape of the soil moisture-holding capacity curve; $D_{\text {smax }}$ is the maximum sub-surface flow rate (in $\mathrm{kg} \mathrm{m}^{-2} \mathrm{~s}^{-1}$ ); $D_{\mathrm{s}}$ is a fraction of $D_{\text {smax }}$. Finally, $W_{\mathrm{s}}$ is a fraction of $w_{\mathrm{m}, \text { bot }}$ (maximum soil moisture in $\mathrm{kg}$ $\mathrm{m}^{-2}$ ).

When the $\mathrm{CN}$ module is enabled, the LAI is predicted using the formula of Thornton and Zimmermann (2007) defined as follow:

$\mathrm{LAI}=\frac{\mathrm{SLA}_{\mathrm{o}} \times\left[\exp \left(m \times C_{L}\right)-1\right]}{m}$,

where $m\left(\mathrm{~m}^{2} \mathrm{gC}^{-1}\right)$ is a linear slope coefficient for each PFT, $\mathrm{SLA}_{\mathrm{o}}\left(\mathrm{m}^{2} \mathrm{gC}^{-1}\right)$ is the specific leaf area at the top of the 
canopy, $C_{L}\left(\mathrm{gC} \mathrm{m}^{-2}\right)$ is the leaf carbon content and $L$ is the predicted leaf area index $\left(\mathrm{m}^{2} \mathrm{~m}^{-2}\right)$. In the CLM45 land model, LAI is predicted for both sunlit and sun-shaded sides as:

$\mathrm{TLAI}=\mathrm{LAI}_{\text {sunlit }}+\mathrm{LAI}_{\text {sunshaded }}$,

where TLAI is the total projected leaf area index.

\subsection{Experiment Design}

The model domain was centered at latitude $5^{\circ}$ and longitude $12^{\circ}$ using a $60 \mathrm{~km}$ horizontal grid-spacing resolution, 18 vertical levels, and 160 horizontal grid points in both zonal and meridional directions (Fig. 1). Three simulations were conducted for 16 years spanning from 01 January 1995 to 31 December 2010. The first three years of each simulation were discarded to allow equilibration of the soil moisture (Steiner et al. 2009). The period from 01 January 1998 to 30 November 2007 was considered for further analysis. Such period was chosen to be consistent with the availability of the Solar Radiation Budget (SRB) reanalysis product. The SP-VIC, CN-TOP, and CN-VIC form the identical-triplet sets of 16-year simulations, which have the same physical parameterization options and initial conditions, with either the vegetation status or the runoff scheme varying between the experiments (see Table 1 file). In all simulations, the PET was calculated using Eq. (3) (see Sect. 1). The boreal summer (June-July-August; JJA) season was selected because it is the rainy season of tropical Africa. Wang et al. (2015) showed that the RegCM4 performance in the West African domain is similar when driven either by the $1.5^{\circ} \times 1.5^{\circ}$ resolution ERA-Interim reanalysis (EIN15; Dee et al. 2011) or the $2.5^{\circ} \times 2.5^{\circ}$ National Centre of Environmental prediction/ National Centre of Atmospheric Research version 2 reanalysis (NCEP/NCAR2; Kanamitsu et al. 2002). In the present study, the NCEP/NCAR version 2 reanalysis data was selected as the initial and the lateral boundary conditions (LBCs), while the EIN15 was used as the prescribed Sea Surface Temperature (SST). A long-term spinning up of the $\mathrm{CN}$ was used to initialize the CN-TOP/CN-VIC simulations with an equilibrium state of the vegetation carbon and net ecosystem exchange as recommended by Fang et al. (2015) and Wang et al. (2015).
Fig. 1 Model domain and topography elevation (unit: meters). Boxes indicate three selected sub-areas: Northern Savannah; (15 W-50 E and 5-15 N), Evergreen Forest (1040 E, 5 S $-5 \mathrm{~N})$ and Southern Savannah (10-40 E, 15-30 S)

\section{ICTP Regional Climatic model V4}

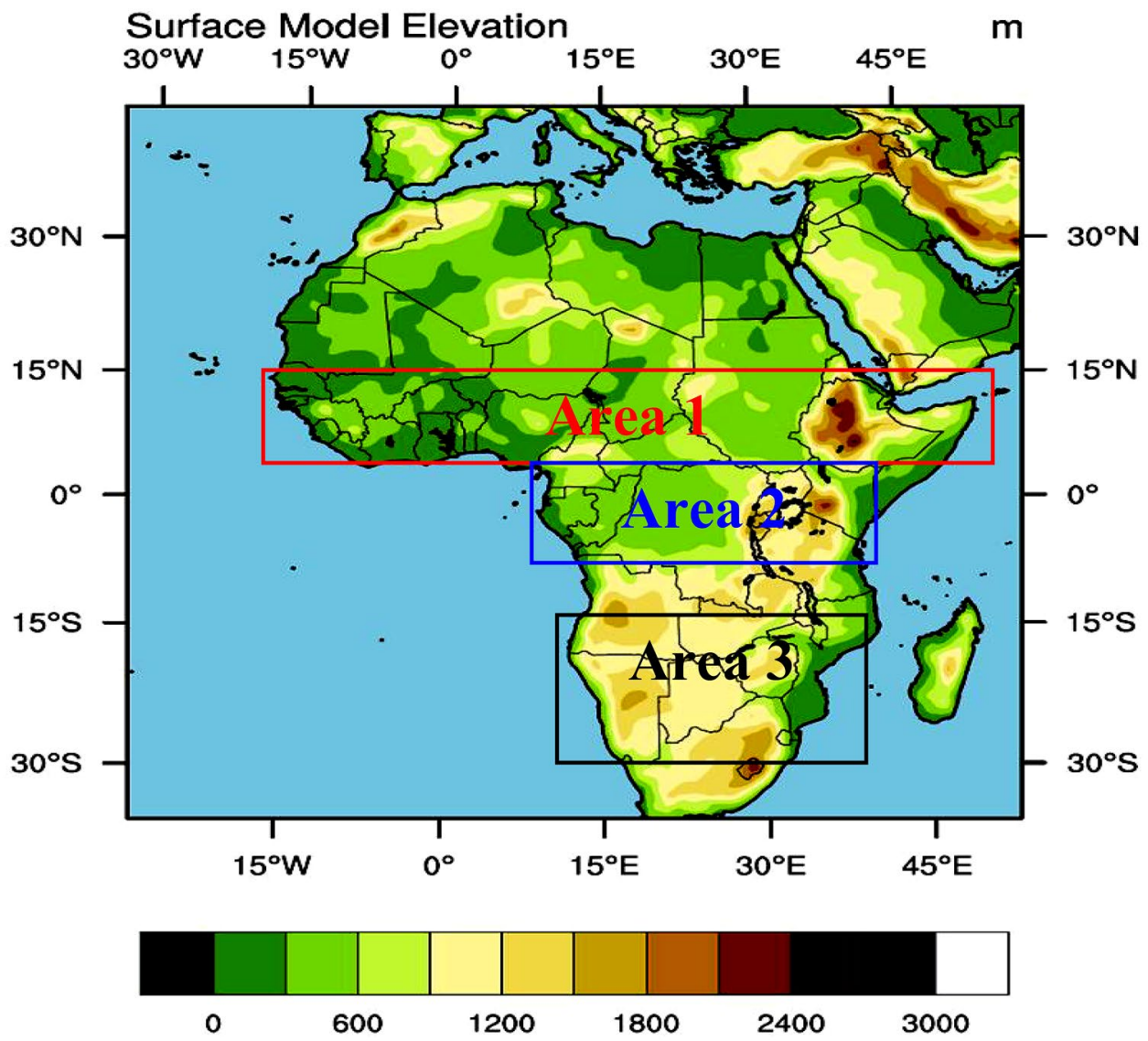


Table 1 Experiment design for the three simulations

\begin{tabular}{|c|c|c|c|c|}
\hline Experiment name & Vegetation status & Runoff scheme & Lateral boundary condition & Note \\
\hline SP-VIC & Static vegetation (SP) & VIC & \multirow{3}{*}{$\begin{array}{l}\text { NCEP/NCAR2 reanalysis }(2.5 \times 2.5 \\
\text { degrees })\end{array}$} & Control simulation \\
\hline $\mathrm{CN}-\mathrm{VIC}$ & $\begin{array}{l}\text { Interactive vegetation, } \\
\text { i.e. carbon-nitrogen } \\
\text { module enabled } \\
(\mathrm{CN})\end{array}$ & VIC & & $\begin{array}{l}\text { The comparison between SP-VIC and } \\
\text { CN-VIC is used to study the influence } \\
\text { of vegetation cover changes only on } \\
\text { the boreal summer PET }\end{array}$ \\
\hline CN-TOP & $\begin{array}{l}\text { Interactive vegetation, } \\
\text { i.e. carbon-nitrogen } \\
\text { module enabled } \\
(\mathrm{CN})\end{array}$ & TOP & & $\begin{array}{l}\text { The comparison between CN-TOP and } \\
\text { CN-VIC is utilized to study the influ- } \\
\text { ence of vegetation-runoff systems on } \\
\text { the boreal summer PET }\end{array}$ \\
\hline
\end{tabular}

All simulations were driven with the same initial and lateral boundary condition (NCEP/NCAR2). The prescribed Sea surface temperature (SST) prescribed forcing over the period 1995-2010 is obtained from the ERA-Interim reanalysis

\subsection{Validation Data}

In this study, the Climatic Research Unit gridded Time Series version 4.05 (CRU TS v4.05; Harris et al. 2020; hereafter CRU) dataset was used to evaluate the RegCM4 model performance. The CRU dataset includes various variables: cloud cover, 2-m diurnal temperature range, frost day frequency, PET, precipitation, 2-m mean, maximum and minimum air temperature as well as vapor pressure. These variables are monthly averaged and integrated over the period 1901-2020. The CRU product is available on a $0.5^{\circ} \times 0.5^{\circ}$ horizontal grid over land domains. The CRU-PET is considered as the best available reference PET data across the globe (Droogers and Allen 2002; Mitchell and Jones 2005; IPCC 2007; Sperna et al. 2012; Potop and Boroneant 2014). Also, Solar Radiation Budget (SRB) reanalysis product was used to evaluate the global incident solar radiation (RSDS). The SRB is a part of the World Climate Research Programme's (WCRP) Global Energy and Water Exchanges (GEWEX) framework, and it covers the period of July 1983 to November 2007.

SRB is constructed on a $1^{\circ} \times 1^{\circ}$ global grid using satellite-derived cloud parameters and ozone fields, reanalysis meteorology, and a few other ancillary data sets. SRB product consists of downward and upward components of shortwave (SW) and longwave (LW) radiation as a major component of the energy exchanges between the atmosphere and land/ocean surfaces and thus affects surface temperature fields, sensible and latent heat fluxes, as well as energy and hydrological cycles. To facilitate the comparison between the model and observation, CRU gridded-observation and SRB reanalysis products were bi-linearly interpolated on the RegCM4-CLM45 horizontal grid. This bi-linear interpolation already used in some previous studies (Diallo et al. 2013; Li et al. 2015; Jia et al. 2019; Libanda and Nkolola 2019; Krishnan and Bhaskaran 2020; Anwar and Diallo 2021c, d; Almazroui et al. 2021; Dosio et al. 2021) has been chosen since it does not impose a significant impact on the spatial distribution of climatology, trends, or biases (Wang et al. 2021).

\section{Results}

Equation (3) shows that PET depends on both the 2-m mean air temperature (T2M) and global incident solar radiation (RSDS). Therefore, it is necessary first to assess the simulated T2M and RSDS with respect to reanalysis products. For instance, Anwar (2021) examined the RegCM4 performance for simulating the T2M with respect to the CRU product. In this study, it was found that the CN-VIC overestimates the T2M more than the SP-VIC with respect to the CRU. This overestimation of T2M will likely affect the simulated PET (see Sect. 3.1). Furthermore, uncertainty of the RSDS was quantitatively evaluated with respect to the Solar Radiation Budget (SRB) reanalysis product (Figure $\mathrm{S} 1$ in supplements). From Figure S1, it can be observed that the RegCM4 overestimates the RSDS in the Sahara region by $20-60 \mathrm{~W} \mathrm{~m}^{-2}$ with respect to the SRB. Also, the CN-VIC reduces the RSDS negative bias by $20-30 \mathrm{~W} \mathrm{~m}^{-2}$ relative to the CN-TOP (which can explain the considerable difference between the two configurations in simulating the PET; see Sect. 3.2).

\subsection{Effects of Vegetation Cover Changes}

In this section, the influence of vegetation cover changes alone was examined. The SP-VIC was considered as the control simulation, while the CN-VIC was considered as the sensitivity simulation. Figure 2 shows the pattern of the spatial distribution for the following variables: $2-\mathrm{m}$ relative humidity (RH2M; in \%, top panels), T2M (in K, middle panels), and RSDS (in $\mathrm{W} \mathrm{m}^{-2}$, bottom panels). The statistical significance of the difference was calculated using a student $t$ test with $\alpha=0.05$. The CN-VIC simulates lower RH2M than the SP-VIC by $15-25 \%$ over all tropical 

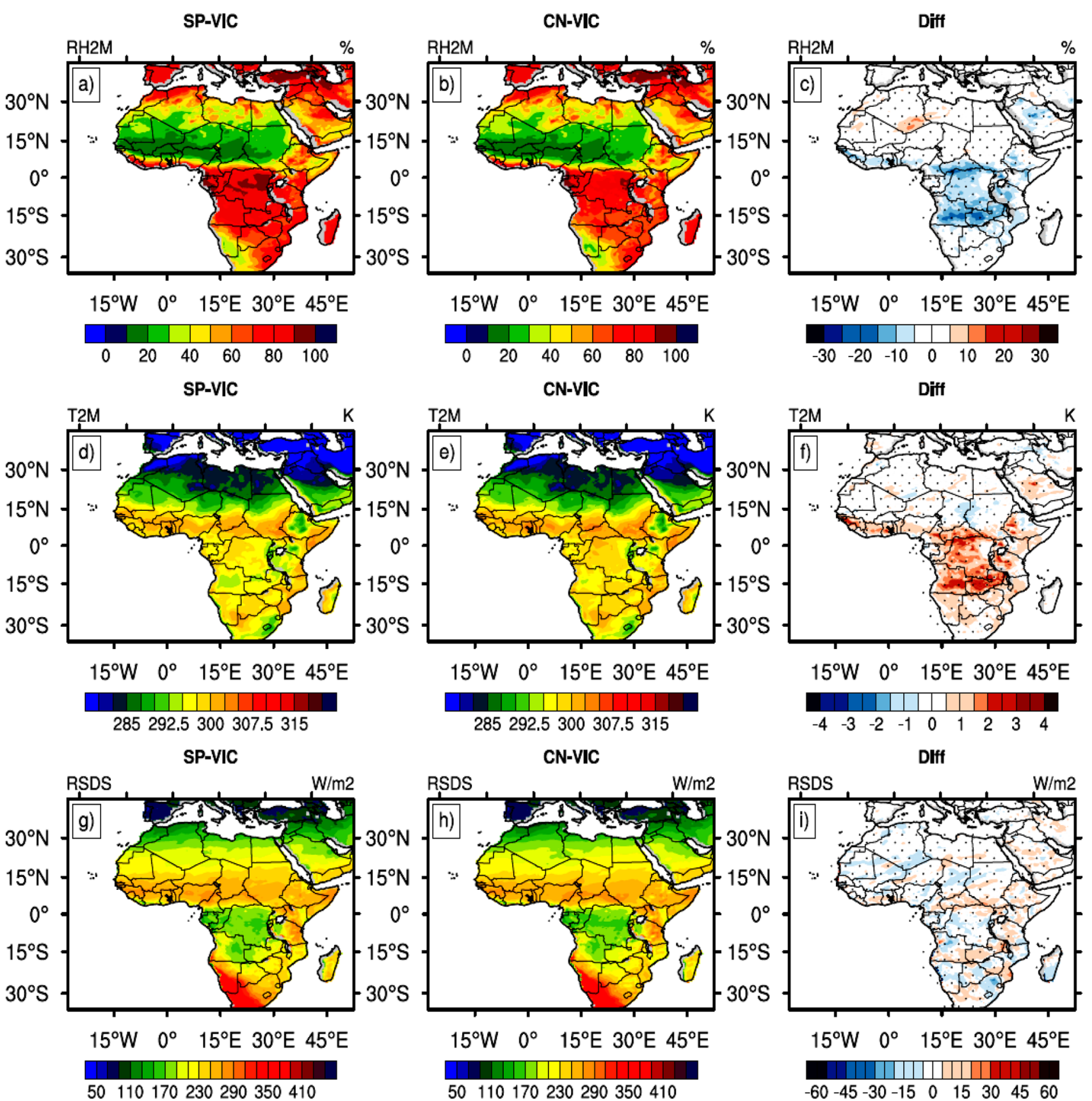

Fig. 2 Spatial pattern of the 2-m relative humidity (RH2M; in \%), 2-m mean air temperature (T2M; in K) and global incident solar radiation (RSDS; in $\mathrm{W} \mathrm{m}^{-2}$ ) over the period 1998-2007 for the boreal summer season (June-July-August; JJA) for the simulations SP-VIC,
CN-VIC and the significant difference (Diff) between the two simulations. The significant difference was calculated using student $t$ test with $\alpha=0.05$

of 1-3 K compared to the SP-VIC (Fig. 2d-f). Regarding the RSDS, the difference between the two simulations is quite small $\left( \pm 5 \mathrm{~W} \mathrm{~m}^{-2}\right)$ (see Figs. $\left.2 \mathrm{~g}-\mathrm{i}\right)$. Figure 3 shows the spatial pattern of the simulated boreal summer PET with respect to the CRU. It is clear that that both simulations reproduce adequately the spatial pattern of the PET with respect to the CRU (Fig. 3a-c). 


\section{Potential Evpotranspiration}
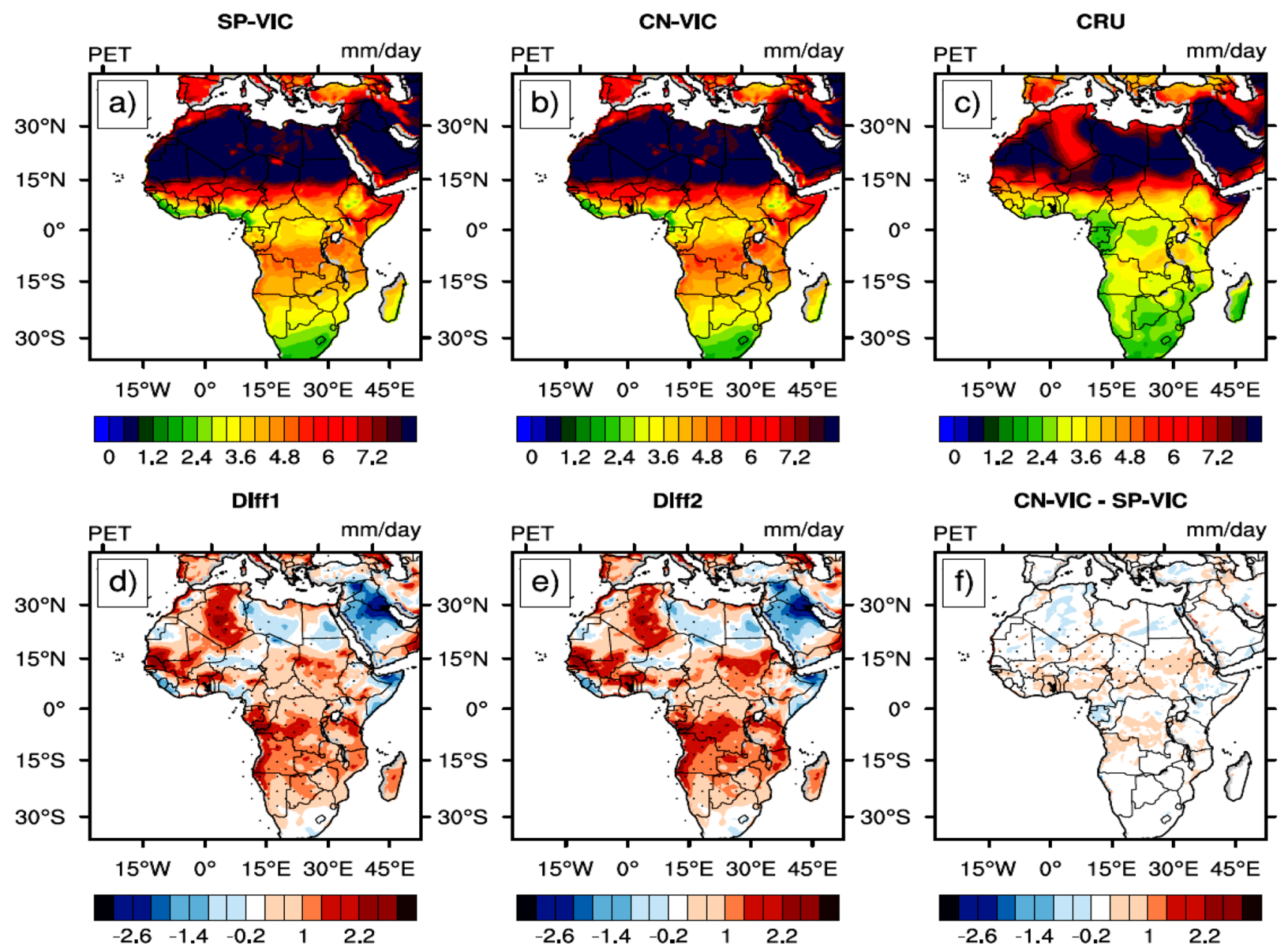

Fig. 3 Averaged potential evapotranspiration (PET; in $\mathrm{mm} \mathrm{day}{ }^{-1}$ ) over the period 1998-2007 for the boreal summer season (June-JulyAugust; JJA). In the first row, SP-VIC is the first panel on the left, $\mathrm{CN}-\mathrm{VIC}$ is the second panel from the left and CRU data is on the

However, the two simulations overestimate the PET by 0.5-2 $\mathrm{mm} \mathrm{day}^{-1}$ particularly over the Northern Savanna and the Congo basin. Such biases of the PET can be partially attributed to the T2M warm biases (Anwar 2021). Qualitatively, the difference between the two simulations is less than $1 \mathrm{~mm} \mathrm{day}^{-1}$ and is only significant over the Northern Savanna (Fig. 3d-f). Overall, our results show that the simulated summer PET doesn't change considerably between the two simulations. Therefore, considering vegetation cover changes alone does not cause a notable change in the simulated PET.

Published in partnership with CECCR at King Abdulaziz University right; the second row shows the fourth (SP-VIC minus CRU; Diff1), (CN-VIC minus CRU; Diff2) and the difference between CN-VIC and SP-VIC. Significant changes are indicated in black dots using student $t$ test with $\alpha=0.05$

\subsection{Effects of Vegetation-Runoff Systems}

The CN-VIC simulates lower RH2M (by 10-30 \%) relative to the CN-TOP (Fig. $4 a-c$ ). This is due to the simulated severe decrease of the TLAI and QVEGT in CN-VIC compared to the CN-TOP as reported in Anwar and Diallo (2021b). In addition, the CN-VIC shows a warmer T2M than the CN-TOP by 2-4 K (Fig. 4d-f). This is a consequence of a considerable overestimation of the sensible heat flux in the CN-VIC compared to the CN-TOP (Anwar and Diallo 2021b). Finally, the CN-VIC simulates higher RSDS than the CN-TOP by about $15-30 \mathrm{~W} \mathrm{~m}^{-2}$ (Fig. $4 \mathrm{~g}-\mathrm{i}$ ). Figure 5 shows the spatial pattern of the simulated boreal summer PET with respect to CRU. It can be seen that both 


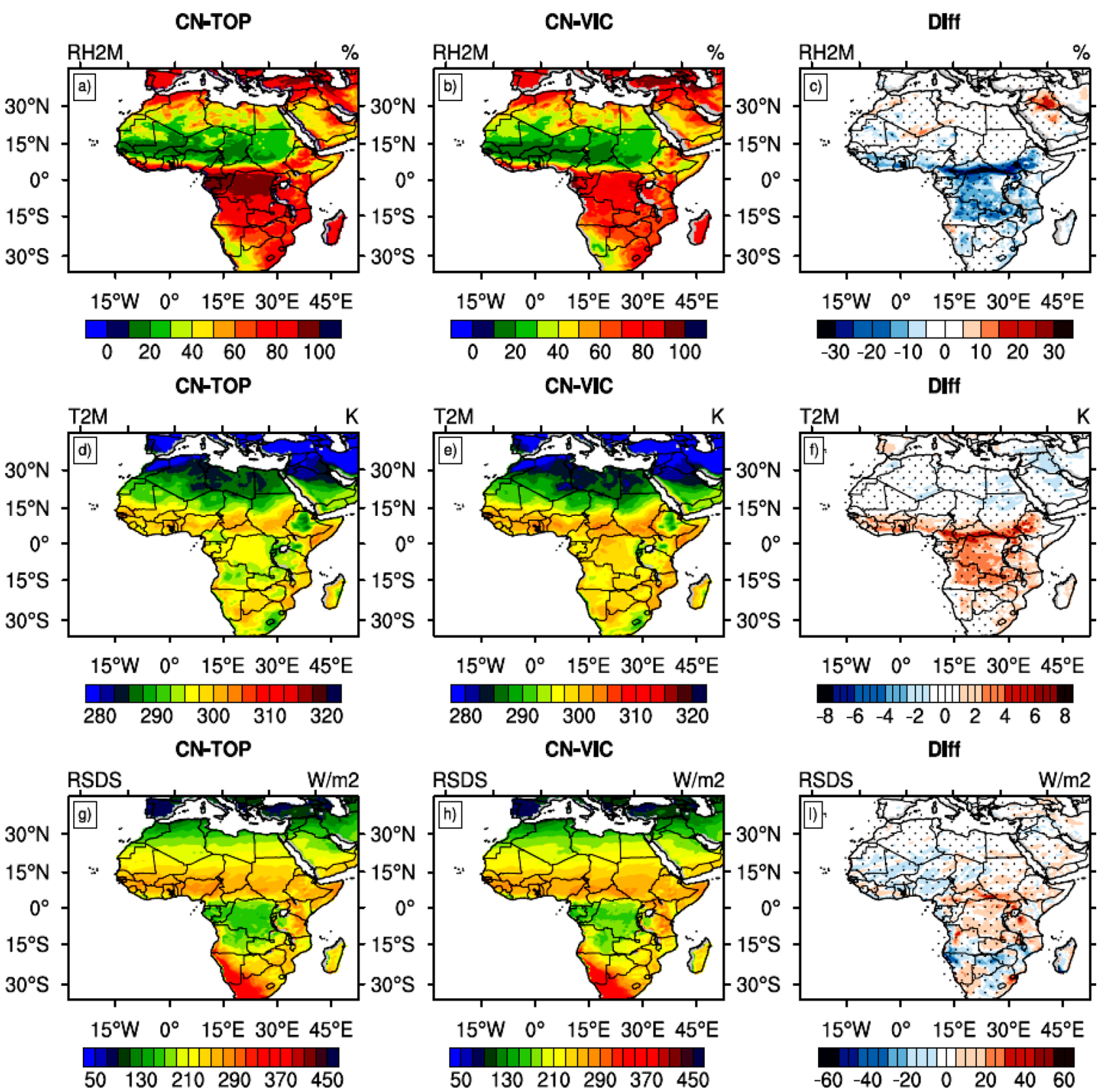

Fig. 4 Spatial pattern of the 2-m relative humidity (RH2M; in \%), 2-m mean air temperature (T2M; in K) and global incident solar radiation (RSDS; in $\mathrm{W} \mathrm{m}^{-2}$ ) over the period 1998-2007 for the boreal summer season (June-July-August; JJA) for the simulations CN-

simulations can capture the spatial pattern of the PET with respect to the CRU (Fig. 5a-c). However, the difference between the two simulations is quite large. The $\mathrm{CN}$ TOP overestimates PET by $1 \mathrm{~mm}$ day $^{-1}$ over Northern and Southern Savanna regions and by $0.4 \mathrm{~mm}^{\mathrm{day}}{ }^{-1}$ over the Congo basin, while the CN-VIC overestimates the PET by 1.2-2.4 $\mathrm{mm} \mathrm{day}^{-1}$ over the entire tropical region. It is thus clear that, the CN-VIC overestimates the PET more than the
TOP, CN-VIC and the significant difference (Diff) between the two simulations. The significant difference was calculated using student $t$ test with $\alpha=0.05$

CN-TOP by $0.8-1.4 \mathrm{~mm} \mathrm{day}^{-1}\left(0.2-0.6 \mathrm{~mm} \mathrm{day}^{-1}\right)$ over the Congo basin (Northern Savanna) (Fig. 5d-f).

The large difference between the two simulations can be linked to the combined changes of the T2M and RSDS. In addition, it can be understood that vegetation-runoff systems have a considerable influence on the simulated PET more than when vegetation cover changes alone. In comparison with the SP-VIC and the CN-VIC, the CN-TOP shows the 


\section{Potential Evpotranspiration}

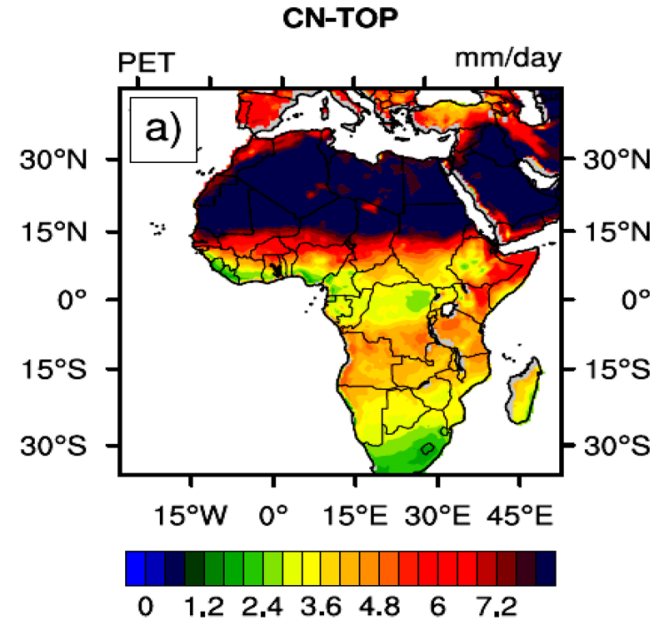

Dlff1

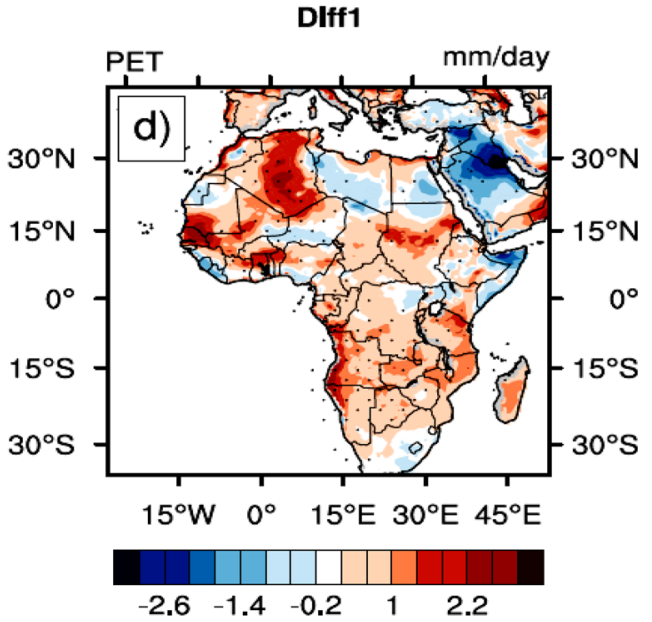

CN-VIC

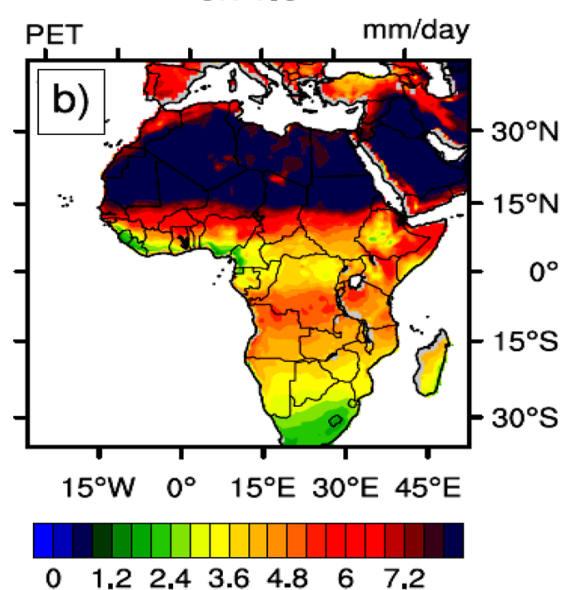

DIff2

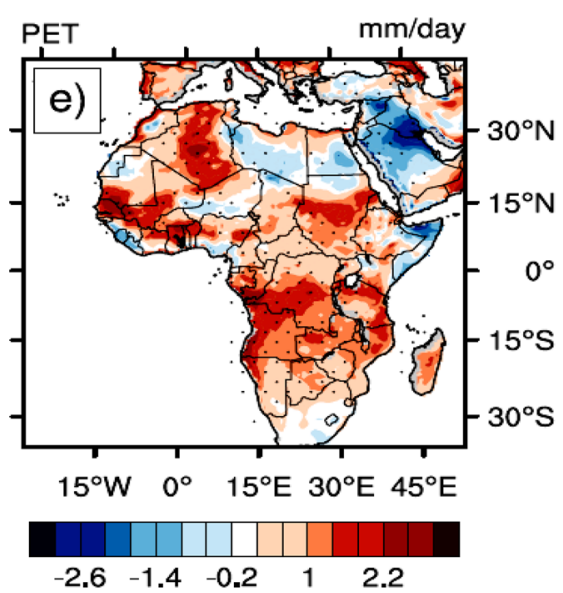

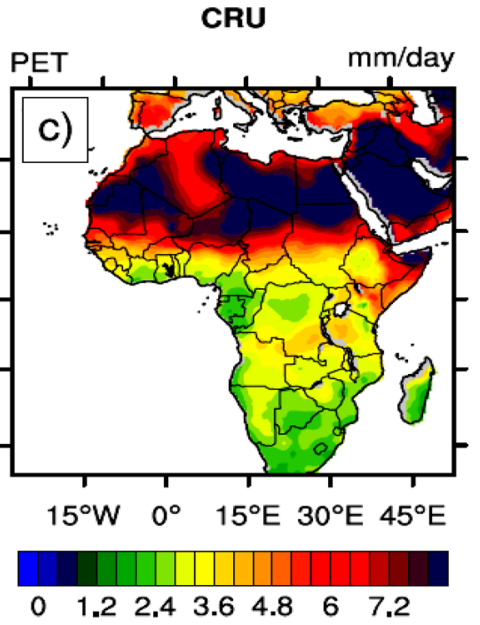

CN-VIC - CN-TOP

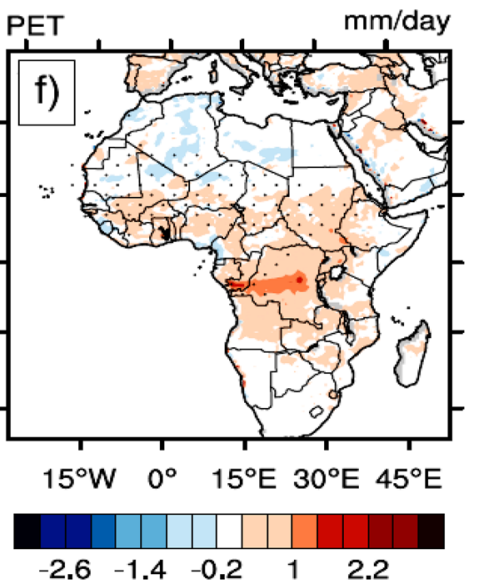

Fig. 5 Averaged potential evapotranspiration (PET; in $\mathrm{mm} \mathrm{day}{ }^{-1}$ ) over the period 1998-2007 for the boreal summer season (June-JulyAugust; JJA). In the first row, CN-TOP is the first panel on the left, $\mathrm{CN}-\mathrm{VIC}$ is the second panel from the left and CRU data is on the

least bias with respect to the observations. However, this bias is still high particularly over both the Northern and Southern Savanna regions. It is worth mentioning that calibrating the HG method (Eq. 3) is necessary to ensure a low bias as suggested by previous studies (Jensen et al. 1997; Vanderlinden et al. 1999; Xu and Singh 2002; Dinpashoh 2006; Murat et al. 2017). Therefore, the constant "17.8" (see Eq. 3) has been adjusted to be "10.8" after conducting various tests. Equation (3) then takes a new form and is rewritten as follow:

$\mathrm{PET}_{\text {HGnew }}=0.0135 \times \operatorname{RSDS} \times\left(T_{\text {mean }}+10.8\right)$,

where the $\mathrm{PET}_{\mathrm{HGnew}}$ is the calculated new PET. Figure 6 shows the spatial pattern of the simulated PET before and after calibrating the HG equation. When Eq. (6) is used, right; the second row shows the fourth (CN-TOP minus CRU; Diff1), (CN-VIC minus CRU; Diff2) and the difference between CN-VIC and CN-TOP. Significant changes are indicated in black dots using student $t$ test with $\alpha=0.05$

RegCM4 simulates the PET with a lower bias than when Eq. (3) is used (Fig. 6a-c). For instance, RegCM4 simulates the $\mathrm{PET}_{\mathrm{HG}}$ with a bias in the range of $0.8-1.6 \mathrm{~mm} \mathrm{day}^{-1}$ over Northern and Southern Savanna regions. However, the biases for the simulated $\mathrm{PET}_{\mathrm{HGnew}}$ are in the range of $\pm 0.4 \mathrm{~mm} \mathrm{day}^{-1}$ (see Fig. 6d-e). Qualitatively, RegCM4 underestimates the $\mathrm{PET}_{\mathrm{HGnew}}$ more than the $\mathrm{PET}_{\mathrm{HG}}$ by $0.2-0.4 \mathrm{~mm} \mathrm{day}^{-1}\left(0.8-1.2 \mathrm{~mm} \mathrm{day}^{-1}\right)$ over the Northern and Southern Savanna regions (the Congo basin) (Fig. 6d-f). To quantitatively evaluate the RegCM4 performance, we plotted (in Fig. 7) the Box-and-Whisker of the boreal summer potential evapotranspiration (PET; in $\mathrm{mm}$ day $^{-1}$ ) before calibrating the HG equation (RegCM4_HG; in blue) and after calibrating the HG equation (RegCM4_HGnew; in red) with respect to the CRU (in green) for the three regions (Northern Savanna, Evergreen Forest and Southern 


\section{Potential Evpotranspiration}
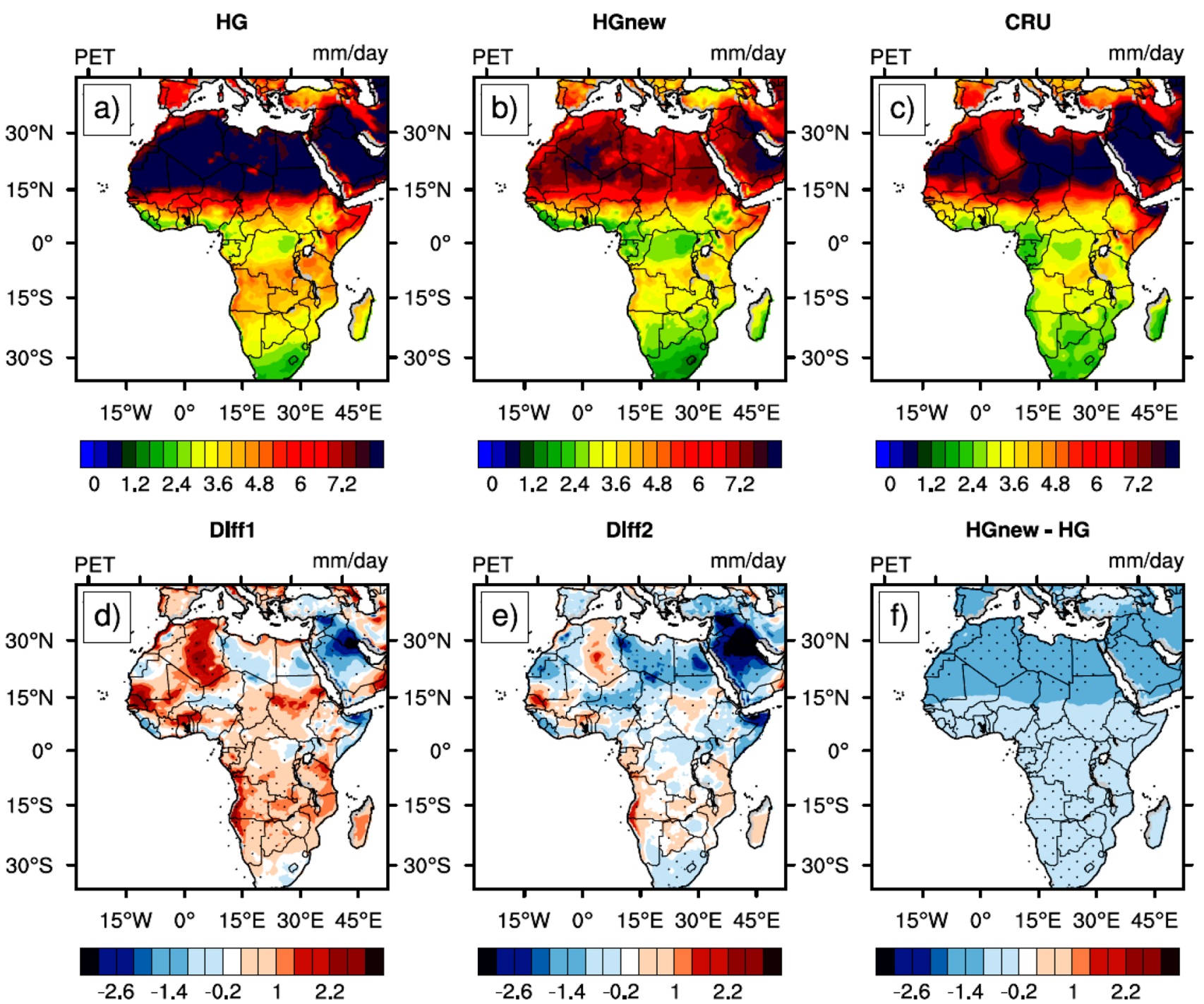

Fig. 6 Averaged potential evapotranspiration (PET; in $\mathrm{mm} \mathrm{day}{ }^{-1}$ ) over the period 1998-2007 for the boreal summer season (June-JulyAugust; JJA) as simulated by the coupled RegCM4-CLM45-CNTOP comparing between the default HG equation (HG) and the calibrated HG equation (HGnew). In the first row, HG is the first panel on the left, HGnew is the second panel from the left and CRU data is on the right; the second row shows the Diff1 (HG minus CRU), Diff2 (HGnew minus CRU) and the difference between HGnew and HG. Significant changes are indicated in black dots using student $t$ test with $\alpha=0.05$
Savanna). This visualization allows displaying measures of the central tendency of data and spreading free from the assumption of a normal distribution. It can be obviously seen that, the RegCM4_HGnew compares better with the CRU than RegCM4_HG particularly over the Evergreen Forest and Southern Savanna regions. Thus, the proposed calibration of the HG method performs better in simulating PET compared to CRU product.

\section{Discussion}

The PET is an essential variable for assessing hydrological and agricultural activities, as well as monitoring drought events. The FAO organization recommends the utilization of the PM method to calculate the PET; but this method requires many meteorological variables. Furthermore, the 

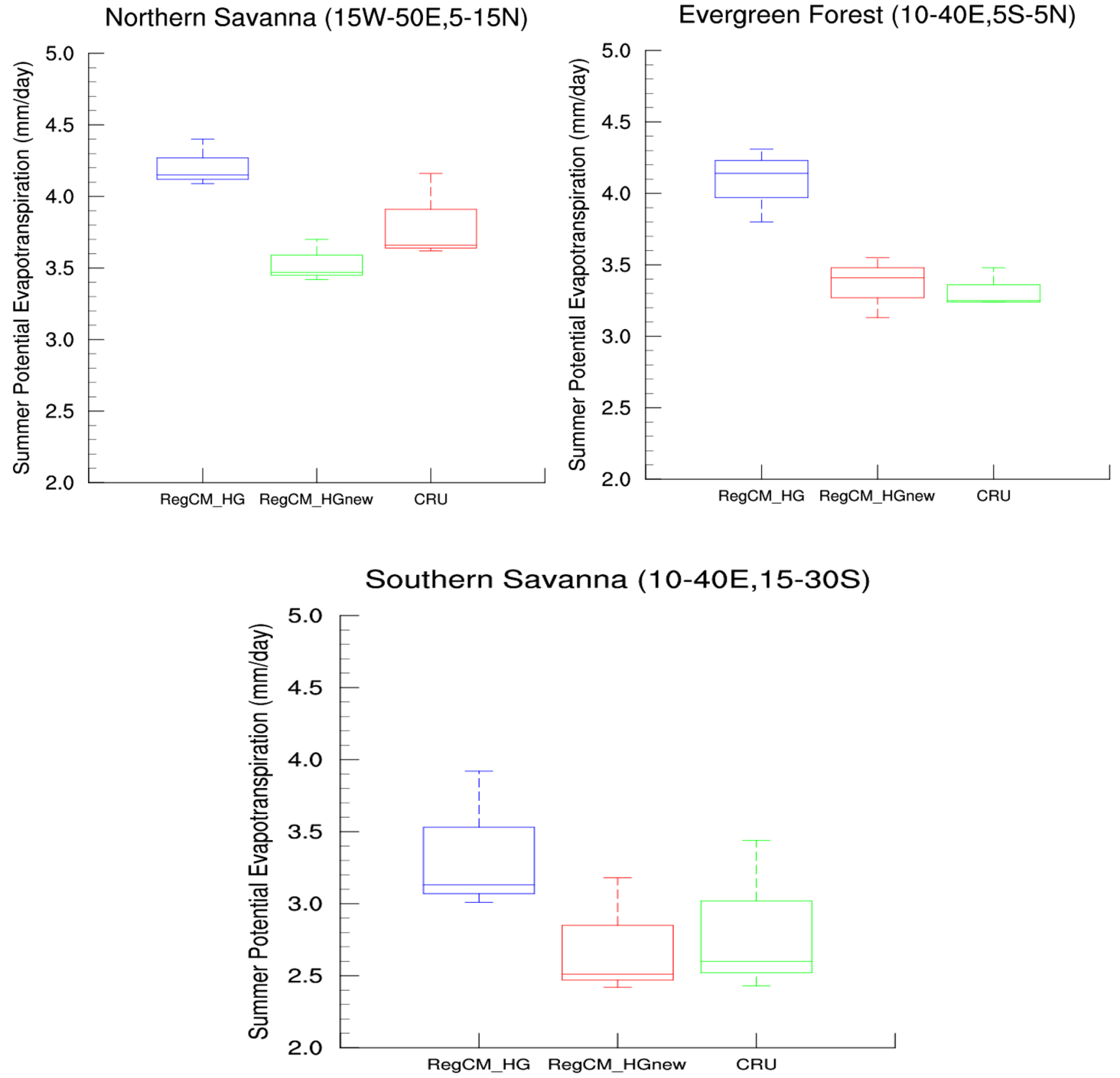

Fig. 7 Box-and-Whisker plot to show the boreal summer potential evapotranspiration (PET; in $\mathrm{mm} \mathrm{day}^{-1}$ ) spread before calibrating the HG equation (RegCM4_HG; in blue) and after calibrating the HG equation (RegCM4_HGnew; in red) with respect to the CRU gridded product (in green) for the three sub-area averages highlighted in Fig. 1 uncertainty of the meteorological variables can amplify the error of the calculated PET (since the PM equation is not linear). Therefore, there was an urgent need to compute the PET using a simple empirical method. Among the temperature-based methods, the HG method was used to compute the PET. We compute PET from the variables simulated by RegCM4, and examine the influence of different physical configurations on the simulated boreal summer PET. Finally, we calibrate the HG method with respect to the CRU product using the RegCM outputs. The results of this study can be summarized as follows:

1. The influence of vegetation cover changes alone induces a little impact on the simulated PET. Larger impact is shown in the vegetation-runoff systems changes.

2. In comparison with the SP-VIC and CN-VIC, the CNTOP shows the least bias with respect to the CRU product. 
3. Using the calibrated $\mathrm{HG}$ equation, the regional coupled model simulation RegCM4-CLM45-CN-TOP shows a very good performance for simulating the boreal summer PET with respect to the CRU gridded-based product.

\section{Conclusions}

We conducted three 16-year simulations to examine the potential influence of changes in the vegetation cover alone and vegetation-runoff systems on the simulated boreal summer PET of tropical Africa. We observed that vegetation-runoff systems affect the PET more than when vegetation cover changes are considered alone. When the calibrated HG equation is used, the regional coupled RegCM4-CLM45-CN-TOP model can be recommended for future studies concerning the PET and the Standardized Precipitation-Evapotranspiration Index (SPEI) of tropical Africa. In our future work, we will address the following points:

1. Incorporating the role of the nitrogen deposition, carbon dioxide $\left(\mathrm{CO}_{2}\right)$, land use land cover changes (LULCC), crops, and aerosols with enabling the dynamic vegetation (DV) using a high-resolution grid-spacing and at a domain similar to the one utilized within the framework of the Coordinated Regional Climate Downscaling Experiment-Africa (CORDEX-Africa; Giorgi et al. 2009; Mariotti et al. 2014).

2. Studying the potential influence of different climate forcing using GCMs participating in the CMIP5/CMIP6 simulations (e.g. Erfanian et al. 2016; Mehboob et al. 2020) on the simulated PET during the reference period and under different global warming scenarios.

The above-mentioned future research works will be supportive to solve the meteorological and environmental related issues in the region.

Supplementary Information The online version contains supplementary material available at https://doi.org/10.1007/s41748-021-00252-3.

Acknowledgements The OFID-ICTP is acknowledged for supporting the fund for the STEP program supported by the Abdus Salam International Centre for Theoretical Physics (ICTP). The Earth System Physics (ESP) of the ICTP is acknowledged for providing the RegCM code, computational facilities, and input data to run the RegCM4 model. The Climate Research Unit (CRU) of the University of East Anglia is acknowledged for providing potential evapotranspiration dataset. SRB data were originally provided by the NASA Langley Research Center Atmospheric Sciences Data Center NASA/GEWEX SRB Project. We would like to thank the three anonymous reviewers and the editor for their constructive comments to improve the manuscript quality.
Author Contributions SAA designed the simulations, wrote the manuscript and analyzed the results. OM, ID, and MBS participated in designing, writing and editing the manuscript.

Funding The authors did not receive support from any organization for the submitted work.

\section{Declarations}

Conflict of interest The authors have no conflicts of interest to declare that are relevant to the content of this article.

Open Access This article is licensed under a Creative Commons Attribution 4.0 International License, which permits use, sharing, adaptation, distribution and reproduction in any medium or format, as long as you give appropriate credit to the original author(s) and the source, provide a link to the Creative Commons licence, and indicate if changes were made. The images or other third party material in this article are included in the article's Creative Commons licence, unless indicated otherwise in a credit line to the material. If material is not included in the article's Creative Commons licence and your intended use is not permitted by statutory regulation or exceeds the permitted use, you will need to obtain permission directly from the copyright holder. To view a copy of this licence, visit http://creativecommons.org/licenses/by/4.0/.

\section{References}

Adeniyi MO (2019) On the influence of variations in solar irradiance on climate: a case study of West Africa. Earth Syst Environ 3:189-202. https://doi.org/10.1007/s41748-019-00103-2

Allen RG, Smith M, Pereira LS, Perrier A (1994) An update for the calculation of reference evapotranspiration. ICID Bull 43:35-92

Allen GR, Pereira SL, Raes D, Smith M (1998) Crop evapotranspiration: guidelines for computing crop water requirements. Food and Agricultural Organization of the United Nations (FAO) Report 56 , Rome, p 300

Almazroui M, Islam MN, Saeed F, Saeed S, Ismail M, Ehsan MA, Diallo I, O’Brien E, Ashfaq M, Martínez-Castro D, Cavazos T, Cerezo-Mota R, Tippett MK, Gutowski WJ Jr, Alfaro EJ, Hidalgo HG, Vichot-Llano A, Campbell JD, Kamil S, Rashid IU, Sylla MB, Stephenson T, Taylor M, Barlow M (2021) Projected changes in temperature and precipitation over the United States, Central America, and the Caribbean in CMIP6 GCMs. Earth Syst Environ 5:1-24. https://doi.org/10.1007/s41748-021-00199-5

Almorox J, Quej VH, Martí P (2015) Global performance ranking of temperature-based approaches for evapotranspiration estimation considering Köppen climate classes. J Hydrol 528:514-522

Andréassian V, Perrin C, Michel C (2004) Impact of imperfect potential evapotranspiration knowledge on the efficiency and parameters of watershed models. J Hydrol 286:19-35

Anwar SA (2021) On the contribution of dynamic leaf area index in simulating the African climate using a regional climate model (RegCM4). Theor Appl Climatol 143:119-129. https://doi.org/ 10.1007/s00704-020-03414-x

Anwar SA, Diallo I (2021a) The influence of two land-surface hydrology schemes on the terrestrial carbon cycle of Africa: a regional climate model study. Int J Climatol 41(Suppl. 1):E1202-E1216. https://doi.org/10.1002/joc.6762

Anwar SA, Diallo I (2021b) On the role of a coupled vegetation-runoff system in simulating the tropical African climate: a regional climate model sensitivity study. Theor Appl Climatol 145:313-325. https://doi.org/10.1007/s00704-021-03627-8 
Anwar SA, Diallo I (2021c) A RCM investigation of the influence of vegetation status and runoff scheme on the summer Gross Primary Production of Tropical Africa. Theor Appl Climatol 145(3):14071420. https://doi.org/10.1007/s00704-021-03667-0

Anwar SA, Diallo I (2021d) Modelling the Tropical African Climate using a state-of-the-art coupled regional climate-vegetation model. Clim Dyn. https://doi.org/10.1007/s00382-021-05892-9

Anwar SA, Zakey AS, Robaa SM, Wahab MM (2019) The influence of two land-surface hydrology schemes on the regional climate of Africa using the RegCM4 model. Theor Appl Climatol 136:1535. https://doi.org/10.1007/s00704-018-2556-8

Ashfaq M, Cavazos T, Reboita MS et al (2020) Robust late twenty-first century shift in the regional monsoons in RegCM-CORDEX simulations. Clim Dyn. https://doi.org/10.1007/s00382-020-05306-2

Bonan G (2008) Forests and Climate Change: Forcings, Feedbacks, and the Climate Benefits of Forests. Science320:1444-9. https:// doi.org/10.1126/science. 1155121

Dee et al (2011) The ERA-Interim reanalysis: configuration and performance of the data assimilation system. QJR Meteorol Soc 137:553-597

Diallo I, Sylla MB, Gaye AT, Camara M (2013) Comparaison du climat et de la variabilité interannuelle de la pluie simulée au Sahel par les modèles climatiques régionaux. Sécheresse 24:96-106. https:// doi.org/10.1684/sec.2013.0382

Diallo I, Giorgi F, Deme A, Tall M, Mariotti L, Gaye AT (2016) Projected changes of summer monsoon extremes and hydro climatic regimes over West Africa for the twenty-first century. Clim Dyn 47:393-3954. https://doi.org/10.1007/s00382-016-3052-4

Dinpashoh Y (2006) Study of reference crop evapotranspiration in I.R. of Iran. Agric Water Manag 84:123-129

Dosio A, Jury MW, Almazroui M et al (2021) Projected future daily characteristics of African precipitation based on global (CMIP5, CMIP6) and regional (CORDEX, CORDEX-CORE) climate models. Clim Dyn. https://doi.org/10.1007/s00382-021-05859-w

Droogers P, Allen RG (2002) Estimating reference evapotranspiration under inaccurate data conditions. Irrig Drain Syst 16:33-45

Erfanian A, Wang G, Yu M, Anyah R (2016) Multi-model ensemble simulations of present and future climates over West Africa: impacts of vegetation dynamics. J Adv Model Earth Syst 8:14111431. https://doi.org/10.1002/2016ms000660

Er-Raki S, Chehbouni A, Khabba S, Simonneaux V, Jarlan L, Ouldbba A, Rodriguez JC, Allen R (2010) Assessment of reference evapotranspiration methods in semi-arid regions: can weather forecast data be used as alternate of ground meteorological parameters? J Arid Environ 74(12): 1587-1596

Fang Y, Liu C, Leung LR (2015) Accelerating the spin-up of the coupled carbon and nitrogen cycle model in CLM4. Geosci Model Dev 8:781-789

Giorgi F, Jone C, Asrar G (2009) Addressing climate information needs at the regional level: the CORDEX framework. Word Meteorol Organ Bull 58(3):175-183

Giorgi F, Coppola E, Solmon F, Mariotti L et al (2012) RegCM4: model description and preliminary tests over multiple CORDEX domains. Clim Res 52:7-29

Guitjens JC (1982) Models of Alfalfa yield and evapotranspiration. J Irrig Drain Syst Proc Am Soc Civ Eng 108(IR3):212-222

Harbeck-Jr GE (1962) A practical field technique for measuring reservoir evaporation utilizing mass-transfer theory. US Geol. Surv., Paper 272-E, pp 101-105

Hargreaves GL, Allen RG (2003) History and evaluation of Hargreaves evapotranspiration equation. J Irrig Drain Eng 129:53-63

Harris I, Osborn TJ, Jones P et al (2020) Version 4 of the CRU TS monthly high-resolution gridded multivariate climate dataset. Sci Data 7:109

IPCC: Climate change 2007: Synthesis report - summary for policy makers 22
Jensen DT, Hargreaves GH, Temesgen B et al (1997) Computation of $\mathrm{ET}_{0}$ under non ideal conditions. J Irrig Drain Eng 123(5):394-400

Jia K, Ruan Y, Yang Y, Zhang C (2019) Assessing the performance of CMIP5 global climate models for simulating future precipitation change in the Tibetan Plateau. Water 11:1771. https://doi.org/10. 3390/w11091771

Kanamitsu M, Ebisuzaki W, Woollen J, Yang SK, Hnilo JJ, Fiorino M, Potter GL (2002) NCEP-DOE AMIP-IIReanalysis (R-2). Bull Am Meteorol Soc 83:1631-1643

Kébé I, Diallo I, Sylla MB, De Sales F, Diedhiou A (2020) Late 21st century projected changes in the relationship between precipitation, African easterly jet, and African easterly waves. Atmosphere 11:353. https://doi.org/10.3390/atmos11040353

Kjelgaard JF, Stokes CO (2001) Evaluating surface resistance for estimating corn and potato evapotranspiration with the Penman-Monteith model. Trans Am Soc Agric Eng 44(4):797-805

Komkoua AJ, Tchawoua C, Vondou DA, Choumbou P, Sadema KC, Deyc S (2017) Sensitivity experiments of RegCM4 simulations to different convective schemes over Central Africa. Int J Climatol 37:328-342. https://doi.org/10.1002/joc.4707

Koster RD, Dirmeyer PA, Guo ZC, Bonan G, Chan E, Cox P, Gordon CT, Kanae S, Kowalczyk E et al (2004) Regions of strong coupling between soil moisture and precipitation. Science 305:11381140. https://doi.org/10.1126/science.1100217

Krishnan A, Bhaskaran PK (2020) Performance of CMIP5 wind speed from global climate models for the Bay of Bengal region. Int J Climatol 40:3398-3416. https://doi.org/10.1002/joc.6404

Lawrence DM, Oleson KW, Flanner MG et al (2011) Parameterization improvements and functional and structural advances in version 4 of the community land model. J Adv Model Earth Syst 3:27

Levis S, Bonan GB, Vertenstein M, Oleson KW (2004) The Community Land Model's Dynamic Vegetation Model (CLM-DGVM): technical description and user's guide. NCAR technical note $\mathrm{TN}-459+\mathrm{IA}$

Li L, Diallo I, Xu CY, Stordal F (2015) Hydrological projections under climate change in the near future by RegCM4 in Southern Africa using a large-scale hydrological model. J Hydrol 528:1-16. https://doi.org/10.1016/j.jhydrol.2015.05.028

Li Z, Yang Y, Kan G (2018) Hong Y (2018) Study on the applicability of the Hargreaves potential evapotranspiration estimation method in CREST distributed hydrological model (version 3.0) applications. Water 10(12): 1882

Liang X, Lettenmaier DP, Wood EF, Burges SJ (1994) A simple hydrologically based model of land surface water and energy fluxes for general circulation models. J Geophys Res 99:14415-14428

Libanda B, Nkolola NB (2019) Skill of CMIP5 models in simulating rainfall over Malawi. Model Earth Syst Environ. https://doi.org/ 10.1007/s40808-019-00611-0

Mamadou O, Cohard JM, Galle S, Awanou CN, Diedhiou A, Kounouhewa B, Peugeot C (2014) Energy fluxes and surface characteristics over a cultivated area in Benin: daily and seasonal dynamics. Hydrol Earth Syst Sci 18:893-914. https://doi.org/10. 5194/hess-18-893-2014

Mamadou O, Galle S, Cohard JM, Peugeot C, Kounouhewa B, Biron R, Hector B, Zannou AB (2016) Dynamics of water vapor and energy exchanges above two contrasting Sudanian climate ecosystems in Northern Benin (West Africa). J Geophys Res Atmos 121(19):11-269

Mariotti L, Diallo I, Coppola E, Giorgi F (2014) Seasonal and intraseasonal changes of African monsoon climates in 21 st century CORDEX projections. Clim Change 125:53-65

Mehboob MS, Kim Y, Lee J, Um MJ, Erfanian A, Wang G (2020) Projection of vegetation impacts on future droughts over West Africa using a coupled RegCM-CLM-CN-DV. Climatic Change. https://doi.org/10.1007/s10584-020-02879-Z 
Mitchell TD, Jones PD (2005) An improved method of constructing a database of monthly climate observations and associated highresolution grids. Int J Climatol 25:693-712. https://doi.org/10. 1002/joc. 1181

Murat C, Hatice C, Tefaruk H, Kisi O (2017) Modifying HargreavesSamani equation with meteorological variables for estimation of reference evapotranspiration in Turkey. Hydrol Res. https://doi. org/10.2166/nh.2016.217

N'Datchoh ET, Diallo I, Konaré A, Silué S, Ogunjobi KO, Diedhiou A, Doumbia M (2018) Dust induced changes on the West African summer monsoon features. Int J Climatol 38:452-466. https://doi. org/10.1002/joc.5187

Nicholson SE, Nash DJ, Chase BM, Grab SW, Shanahan TM, Verschuren D, Asrat A, Lézine A-M, Umer M (2013) Temperature variability over Africa during the last 2000 years. Holocene 23(8):1085-1094. https://doi.org/10.1177/0959683613483618

Niu GY, Yang ZL, Dickinson RE, Gulden LE (2005) A simple TOPMODEL-based runoff parameterization (SIMTOP) for use in global climate models. J Geophys Res 110:D21106. https://doi. org/10.1029/2005JD006111

Ogwang BA, Chen H, Li X, Gao C (2016) Evaluation of the capability of RegCM4.0 in simulating East African climate. Theor Appl Climatol 124:303-313. https://doi.org/10.1007/s00704-015-1420-3

Oleson KW, Lawrence DM, Bonan GB et al (2013) Technical description of version 4.5 of the Community Land Model (CLM). NCAR technical note NCAR/TN-503 + STR. National Center for Atmospheric Research, Boulder

Penman HL (1948) Natural evaporation from open water. Bare soil and grass. Proc R Soc Lond 193:120-145

Pielke RA, Marland G, Betts RA, Chase TN, Eastman JL, Niles JO, Niyogi DS, Running SW (2002) The influence of land-use change and landscape dynamics on the climate system: relevance to climate-change policy beyond the radiative effect of greenhouse gases. Philos Trans R Soc Lond Math Phys Eng Sci 360:17051719. https://doi.org/10.1098/rsta.2002.1027

Potop V, Boroneant C (2014) Assessment of potential evapotranspiration at Chisinau station. Mendel a bioklimatologie, Brno, pp 3-5

Priestley CHB, Taylor RJ (1972) On the assessment of the surface heat flux and evaporation using large-scale parameters. Mon Weather Rev 100:81-92

Sawadogo W, Reboita MS, Faye A et al (2020) Current and future potential of solar and wind energy over Africa using the RegCM4 CORDEX-CORE ensemble. Clim Dyn. https://doi.org/10.1007/ s00382-020-05377-1

Sheikh V, Mohammadi M (2013) Evaluation of reference evapotranspiration equations in semi-arid regions of Northeast of Iran. IJACS/5-5/450-456

Sperna FC et al (2012) Selecting the optimal method to calculate daily global reference potential evaporation from CFSR reanalysis data for application in a hydrological model study. Hydrol Earth Syst Sci 16:983-1000. https://doi.org/10.5194/hess-16-983-2012

Steiner AL, Pal J, Rauscher SA, Bell JL, Diffenbaugh NS, Boone A, Sloan LC, Giorgi F (2009) Land surface coupling in regional climate simulations of the West African monsoon. Clim Dyn 33:869-892. https://doi.org/10.1007/s00382-009-0543-6

Sylla MB, Giorgi F, Pal JS, Gibba P, Kebe I, Nikiema M (2015) Projected changes in the annual cycle of high intensity precipitation events over West Africa for the late 21st century. J Clim 28:64756488. https://doi.org/10.1175/JCLI-D-14-00854.1

Taylor CM, de Jeu RAM, Guichard F, Harris PP, Dorigo WA (2012) Afternoon rain more likely over drier soils. Nature 489:423-426. https://doi.org/10.1038/nature11377

Thornthwaite CW (1948) An approach toward a rational classification of climate. Geogr Rev 38:55-94
Thornton PE, Rosenbloom NA (2005) Ecosystem model spin-up: estimating steady state conditions in a coupled terrestrial carbon and nitrogen cycle model. Ecol Model 189:25-48

Thornton PE, Zimmermann NE (2007) An improved canopy integration scheme for a land surface model with prognostic canopy structure. J Clim 20:3902-3923

Vanderlinden K, Romero A, Reina D, Giráldez JV (1999) Evaluación del método de Hargreaves en 16 estaciones completas de Andalucia. In: Proceedings of the XVII Congreso Nacional de Riegos, Murcia, Spain, 11-13 May 1999, pp 92-99

Vicente-Serrano SM, Azorin-Molina C, Sanchez-Lorenzo A, Revuelto J, López-Moreno JI, González-Hidalg JC, Moran-Tejeda E, Espejo F (2014) Reference evapotranspiration variability and trends in Spain, 1961-2011. Glob Planet Change 121:26-40

Wang G, Yul M, Pal JS, Mei R, Bonan GB, Levis S, Thornton PE (2015) On the development of a coupled regional climate-vegetation model RCM-CLM-CN-DV and its validation in Tropical Africa. Clim Dyn. https://doi.org/10.1007/s00382-015-2596-Z

Wang Z, Zhan C, Ning L (2021) Guo H (2021) Evaluation of global terrestrial evapotranspiration in CMIP6 models. Theor Appl Climatol 143:521-531. https://doi.org/10.1007/s00704-020-03437-4

$\mathrm{Xu}$ CY, Singh VP (2002) Cross comparison of empirical equations for calculating potential evapotranspiration with data from Switzerland. Water Resour Manag 16:197-219

Yang Y (2015) Introduction. In: Evapotranspiration over heterogeneous vegetated surfaces. Springer Theses (Recognizing Outstanding Ph.D. Research). Springer, Berlin. https://doi.org/10.1007/ 978-3-662-46173-0_1

Yu M, Wang G, Pal JS (2015) Effects of vegetation feedback on future climate change over West Africa. Clim Dyn. https://doi.org/10. 1007/s00382-015-2795-7

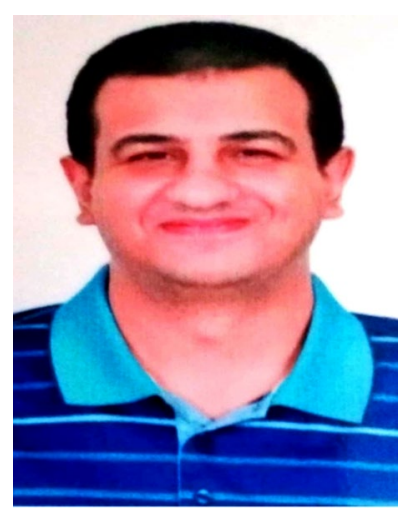

Samy A Anwar is a researcher in the research department in the Egyptian Meteorological Authority (EMA). His PhD degree is from Cairo University in collaboration with the International Center of Theoretical Physics (ICTP) through STEP program. His major research involves the role of land-surface processes in constraining the surface climate and terrestrial carbon cycle of tropical Africa using a regional climate model (RegCM4).

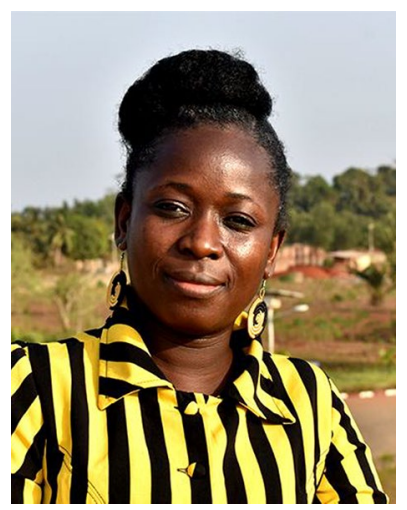

Ossénatou Mamadou is a Lecturer at the Institute of Mathematics and Physical Sciences, The University of AbomeyCalavi, Bénin. Her expertise covers Atmospheric Physics; Radiation in the atmosphere; Micrometeorology; Boundary Layer Processes and Eddy Covariance data treatment. Her current research focuses on the underlying physical processes in the Atmospheric BoundaryLayer and their relationship with the climate, to propose better parameterization tools for them. 


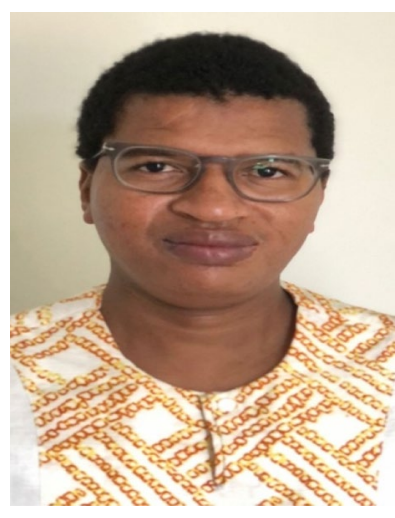

Ismaillo Diallo is an Assistant Research Professor at Center for Earth System Modeling, Analysis, and Data (ESMAD), Department of Meteorology and Atmospheric Science, The Pennsylvania State University. His research interests include regional climate downscaling, land surface modeling, land/ atmosphere/ocean interactions, climate variability, anomalies, and change, tropical climate and remote sensing.

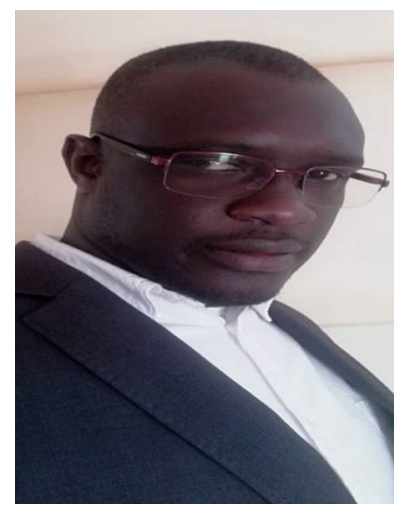

Mouhamadou Bamba is the AIMS-Canada Research Chair in Climate Change Science based in Kigali, Rwanda. Prior to this, he was the senior scientist in climate modeling and climate change at WASCAL Competence Center, Ouagadougou, Burkina Faso. Within the same institution and simultaneously with this, he was also appointed as head of climate change and climate variability research cluster, acting coordinator of observation networks and acting director of research at different periods of time. Dr. Sylla completed a postdoc at the ICTP, Trieste, Italy and a research scholar and part-time lecturer at LMU I LA, California, USA. His research interests focus on regional climate modeling, anthropogenic climate change, climate change impacts, extremes, hazards and dynamics. 